\title{
Pelaksanaan Fungsi Legislasi Dewan Perwakilan Rakyat Daerah (DPRD) Kabupaten Buton Utara Terhadap Pembuatan Peraturan Daerah Tahun 2015-2018
}

\author{
Sry Wulan Yunita Swari ${ }^{1}$, Mansur $^{2}$, Andy Arya Maulana Wijaya ${ }^{3}$ \\ 1Mahasiswa Ilmu Pemerintahan UM. Buton \\ 2Dosen FISIP UM. Buton \\ ${ }^{3}$ Dosen FISIP UM. Buton
}

\begin{abstract}
Abstrak, Tujuan Penelitian ini adalah untuk mengamati pelaksanaan Fungsi Legislasi oleh DPRD Kabupaten Buton Utara dalam pembuatan Peraturan Daerah pada tahun 2015. Serta, mengidentifikasi sejumlah factor yang dapat mempengaruhi fungsi legislasi DPRD tersebut. Penelitian deskriptif kualitatif, dengan menggunakan purposive sampling dalam menentukan informan penelitian. Pengumpulan data dilakukan dengan wawancara mendalam (indepth interview), observasi langsung dan studi dokumen. Data kemudian dianalisis secara interaktif dan disajikan dalam bentuk deskriptif. Hasil penelitian ini menunjukkan bahwa pelaksanaan fungsi legislasi oleh DPRD Kabupaten Buton Utara berjalan optimal, dimana fungsi ini dijalankan sesuai dengan Peraturan Daerah Kabupaten Buton Utara Nomor 7 Tahun 2015 tentang Pembentukan Produk Hukum Daerah, dimana tahapan pembentukan Peraturan Daerah ditingkat DPRD yaitu 1) Perencanaan, 2) Penyusunan, 3) Pembahasan yang melalui Pembicaraan tingkat I dan II, 4) Penetapan, dan 5) Pengundangan/penyebarluasan. Hanya saja dalam pembentukan PERDA tahun 2015 lebih banyak berasal dari inisiatif Pemerintah Daerah. Faktor-faktor yang mempengaruhi dalam pembuatan PERDA adalah Dinamika Politik, Kapabilitas Anggota dan Ruang Aspirasi Masyarakat.
\end{abstract}

Kata Kunci : Legislasi, Peraturan Daerah, DPRD, Kabupaten Buton Utara

\begin{abstract}
The purpose of this study was to observe the implementation of the Legislation Function by the North Buton Regency DPRD in making Regional Regulations in 2015. As well as, identify a number of factors that could influence the legislative function of the DPRD. Qualitative descriptive research, using purposive sampling in determining research informants. Data collection is done by in-depth interviews (indepth interviews), direct observation and document study. Data is then analyzed interactively and presented in descriptive form. The results of this study indicate that the implementation of the legislative function by the North Buton Regency DPRD runs optimally, where this function is carried out in accordance with the North Buton District Regulation Number 7 of 2015 concerning the Establishment of Regional Legal Products, where the stages of Regional Regulations at the DPRD level are ) Preparation, 3) Discussion through Level I and II Talks, 4) Determination, and 5) Enactment / dissemination. It's just that in the 2015 PERDA formation more came from the initiative of the Regional Government. The factors that influence the making of PERDA are Political Dynamics, Member Capability and Community Aspiration Space.
\end{abstract}

Keywords: Legislation, Regional Regulation, DPRD, North Buton Regency 


\section{Pendahuluan}

Reformasi di Indonesia telah membawa banyak perubahan baik dalam struktur maupun kultur penyelenggaraan pemerintahan. Perubahan ini juga menyangkut sebaran kekuasaan penyelenggaraan pemerintahan, yakni eksekutif, legislative dan yudikatif. Dalam kajian ini memfokus pada Lembaga legislatif yang adalah salah satu unsur penyelenggaraan pemerintahan, lembaga ini disebut Dewan Perwakilan Rakyat (DPR) yang untuk tingkat daerah disebut Dewan Perwakilan Rakyat Daerah (DPRD). Kekuasaan yang dimiliki lembaga legistlatif tercermin dalam fungsinya dalam legislasi, anggaran, dan pengawasan. Anggota DPR dipilih oleh rakyat secara langsung melalui suatu Pemilihan umum, agar dapat mewakili rakyat dalam menyalurkan kepentingannya.

Otonomi daerah hingga saat ini telah berbicara banyak tentang kondisi penyelenggaraan pemerintahan, sekalipun banyak ahli yang menganggap bahwa otonomi daerah masih menyisakan banyak persoalan pada tataran teknisnya. Salah satunya yang dapat dijadikan cerminan disini adalah pembagian kekuasaan eksekutif (Pemerintah) dan legislative (DPRD), yang seringkali terlibat dalam konflik politik daerah. Padalah mestinya kedua lembaga kekuasaan tersebut dapat beriringan dalam upaya mensejahterakan masyarakatnya.

Dalam hal kebijakan publik tentu kedua lembaga ini harus mensinergikan tugas-tugasnya untuk menyajikan kebijakan yang berpihak pada rakyat. Hari ini, terbangun pendapat jika terjadi kesalahan-kesalahan dalam penyelenggaraan pemerintahan didaerah maka yang akan menuai kritik adalah pemerintah daerah dalam hal ini eksekutif, akan tetapi legislative (DPRD) terkesan tidak ada hubungannya dengan kesalahan tersebut. Padahal kedua lembaga ini memiliki peran dan fungsi yang penting dalam mewujudkan penyelenggaraan pemerintahan yang efektif di daerah.

Dalam Undang-undang No 23 Tahun 2014 tentang Pemerintah Daerah menyebutkan bahwa Dewan Perwakilan Rakyat Daearah (DPRD) merupakan lembaga perwakilan rakyat daerah, yang berkedudukan sebagai unsur penyelenggara pemerintahan daerah, dan merupakan mitra kerja pemerintah daerah. DPRD telah dibekali dengan sejumlah hak yang tentu saja kalau dijalankan dengan baik akan mengakibatkan lembaga tersebut akan mampu memainkan peranan yang sangat 
kuat dalam menciptkan checks and balances dengan pihak eksekutif (Syaukani, dkk. 2005: 192).

Kabupaten Buton Utara yang merupakan daerah otonomi baru, tentu memproduk sejumlah kebijakan melalui Peraturan Daerah. Hal ini memerlukan kerja bersama antara eksekutif dan legislative di daerah. Sejalan dengan pembentukan pemerintahan Kabupaten Buton Utara dilakukan juga pengangkatan anggota DPRD yang berjumlah 20 orang. Melalui Pemilu pada tahun 2014, terpilih 20 anggota DPRD Kabupaten Buton Utara yang terdiri dari 17 Orang Laki-Laki dan 3 Orang Perempuan untuk periode 20142019. Terbagi dalam 3 Fraksi yakni Fraksi Amanah Rakyat sebanyak 9 orang, Fraksi Golkar sebanyak 3 orang dan Fraksi Gabungan sebanyak 9 orang (Demokrat, PDIP, Gerindra, KNPI PKS, PKB dan Hanura).

Pada tahun 2015, DPRD Kabupaten Buton Utara mengklaim berhasil Jalankan Tugas (http://hariansultra.com/dprdbuton-utara-godok-empat-raperdadesa/diakses, 20/11/2015). Peran Dewan Perwakilan Rakyat Daerah (DPRD) Kabupaten Buton Utara dalam merumuskan Perda akan berkorelasi dengan kemampuan individu didalamnya. Anggota DPRD Kabupaten Buton Utara tentu harus paham dan mengerti terkait proses perumusan dan Penetapan Perda, sebagai bentuk pemahaman terhadap salah satu fungsinya yakni fungsi legislasi di daerah. Kewenangan tersebut tentu harus diarahkan pada tujuan-tujuan daerah yang muaranya pada kepentingan masyarakat. DPRD sebagai mitra pemerintah daerah (eksekutif) adalah sebagai media checks and balances dalam penyelanggaraan pemerintahan daerah, disamping juga masyarakat harus berdaya dalam melakukan pengawasan terhadap kinerja pemerintah daerahnya, dan paham proses penetapan sebuah peraturan daerah.

Berdasarkan deskripsi diatas, penelitian ini memberikan fokus kajian pada peran legislasi dari DPRD Kabupaten Buton Utara. Hanya saja kajian ini memberikan titik berat pada kajian kualitatif namun juga diperkuat dengan survey opini melalui data kuantitatif.

\section{Metode Penelitian}

Jenis penelitian ini adalah kualitatif dengan tipe penelitian deskriptif yang bermaksud untuk memberikan uraian mengenai suatu gejala social yang diteliti, penelitian ini dilakukan dengan cara deskriptif kualitatif yakni berusaha mendeskripsi kualitas suatu gejala yang menggunakan ukuran urusan sebagai dasar penilaian (Slamet, 2006: 7). 
Disamping itu penelitian deskriptif menggunakan metode survey Atherton \& Klemmack (1982; dalam Soehartono, 2008: 35) yaitu dengan mengumpulkan dan menganalisis suatu peristiwa atau proses tertentu dengan memilih data atau menentukan ruang lingkup tertentu sebagai sampel yang dianggap representatif.

\section{Hasil Penelitian}

\section{a. Proses Pembuatan Peraturan Daerah (PERDA) oleh Dewan Perwakilan Daerah Kabupaten Buton Utara}

Kebijakan yang baik akan menentukan arah pembangunan yang baik pula bagi sebuah daerah. Dalam konteks kebijakan daerah, salah satunya dikenal dengan nama Peraturan Daerah (Perda). Undang-undang No 23 Tahun 2014 tentang Pemerintah Daerah pasal 236 ayat (1) dan (2), menyebutkan bahwa untuk menyelenggarakan Otonomi Daerah dan Tugas Pembantuan, Daerah membentuk Perda. Dimana Perda dibentuk oleh Dewan Perwakilan Rakyat Daerah (DPRD) dengan persetujuan bersama Kepala Daerah.

Selain itu, Pasal 149 UndangUndang 23 Tahun 2014 tentang Pemerintah Daerah juga menyebutkan proses penyusunan Peraturan Daerah (Perda) melalui beberapa tahapan, yaitu
Perencanaan, Penyusunan, Pembahasan, Penetapan dan Pengundangan. Peraturan Daerah disusun dengan maksud penyelenggaraan otonomi daerah dan tugas pembantuan, dan juga sebagai penjabaran lebih lanjut tentang peraturan perundang-undangan diatasnya. Sedangkan isi dan tujuan penyusunan Perda ditentukan berdasarkan pada muatan lokal masing-masing daerah.

Konteks Kabupaten Buton Utara, penyusunan Peraturan Daerah selain berpedoman pada aturan perundangundangan yang berlaku, namun juga disusun dalam Peraturan Dewan Perwakilan rakyat Daerah Kabupaten Buton Utara Nomor 1 Tahun 2014 Tentang Tata Tertib Dewan Perwakilan rakyat Daerah Kabupaten Buton Utara, dan Peraturan Daerah Kabupaten Buton Utara Nomor 7 Tahun 2015 tentang Tata Cara Pembentukan Produk Hukum Daerah.

Begitupun juga yang terjadi di Kabupaten Buton Utara, perumusan peraturan daerah dilakukan bersamasama antara pihak Pemerintah Daerah dan DPRD Kabupaten Buton Utara. Pembahasan Ranperda dilakukan melalui Badan Pembentukan Peraturan Daerah yang dibentuk berdasarkan Surat Keputusan Dewan Perwakilan Rakyat Daerah Kabupaten Buton Utara Bulan November Tahun 2014. 
Materi muatan Peraturan Daerah adalah seluruh materi muatan dalam rangka penyelenggaraan otonomi daerah dan tugas pembantuan, dan menampung kondisi khusus daerah serta penjabaran lebih lanjut Peraturan Perundangundangan yang lebih tinggi. Adapun prosedur pembentukan Ranperdan untuk kemudian menjadi Perda di DPRD Kabupaten Buton Utara, yaitu ;

\section{Tahap Perencanaan}

Perencanaan merupakan Program Legislasi Daerah (Prolegda) sebagai landasan operasional pembangunan hukum di daerah melalui pembentukan peraturan perundang-undangan, seharusnya akan dapat memproyeksikan kebutuhan hukum atau peraturan daerah, baik secara kualitatif maupun kuantitatif dengan menetapkan visi dan misi, arah kebijakan, serta indikator secara rational. Sehingga Program Legislasi Daerah mengandung kegiatan dalam kurun waktu lima tahun atau satu tahun anggaran yang memiliki nilai strategis yang akan direalisasikan sebagai bagian dari pembangunan daerah secara keseluruhan.

Perencanaan yang dilakukan untuk mengatur tata cara penyusunan dan pengelolaan Prolegda serta tata cara mempersiapkan ranperda yang berasal dari kepala daerah atau dari inisiatif DPRD, berjalan sesuai aturan yang ada.
Dimana pelaksanaan Program Legislasi Daerah dapat disusun secara terkoordinasi, terarah, dan terpadu yang disusun bersama oleh DPRD dan Pemerintah Daerah (Kepala Daerah) serta mengikat kepada semua kepala daerahkepala daerah maupun dari masyarakat di masing-masing daerah otonom dalam hal tata cara mempersiapkan ranperda dilingkungannya.

Anggota DPRD secara aktif terlibat dalam penyusunan peraturan daerah, tidak hanya menyetujui draf yang dipersiapkan oleh pemerintah, dan memainkan peran penting dalam proses penganggaran daerah. Disamping itu juga, Anggota DPRD menyiapkan Naskah Akademik dari Rancangan Perda yang diajukan. Dimana naskah akademik ini berisi hasil penelitian atau pengkajian hukum dan hasil penelitian lainnya terhadap suatu masalah tertentu yang dapat dipertanggungjawabkan secara ilmiah dalam suatu rancangan Ranperda. Tugas ini memang menurut amatan penulis cukup sulit, karena diperlukan adanya kapabilitas dan kapasitas dari anggota DPRD itu sendiri.

Selama periode saat ini, memang diakui bahwa Ranperda sebagian besar berasal dari inisiatif pemerintah daerah. Hanya terdapat beberapa yang merupakan usulan langsung dari DPRD Kabupaten 
Buton Utara. Walaupun memang diakui bahwa kinerja dalam pembentukan Ranperda adalah hasil kerja sama antara Pemerintah Daerah dan DPRD, namun kinerja yang sama produktifnya juga perlu ditunjukkan oleh DPRD.

\section{Tahap Penyusunan}

Penyusunan Peraturan Daerah dalam hal ini pengajuan RANPERDA, dapat berasal dari DPRD atau Kepala Daerah (Bupati) dan dilakukan dengan menyampaikan Draft Ranperda kepada Badan Pembuatan Peraturan Daerah DPRD Kabupaten Buton Utara. Selanjutnya kemudian, proses pembentuka Perda dilakukan bersama-sama antara DPRD dan disetujui oleh Kepala Daerah.

Pada prosesnya, DPRD dan pemerintah daerah membuka pintunya untuk masukan dari kelompok-kelompok masyarakat sipil. Dalam beberapa kasus, hal ini telah dilembagakan melalui kebijakan lokal untuk melibatkan organisasi masyarakat sipil dalam proses penyusunan peraturan daerah.

Sedangkan Ranperda yang merupakan hasil usulan Kepala Daerah dilakukan oleh Instansi Teknis dalam hal ini adalah Bagian Hukum dan Perundangundangan Pemerintah Daerah Kabupaten Buton Utara. Dalam proses ini Pemda menentukan suatu kebijakan yang hasilnya dibuat dalam suatu draf yang nantinya akan disampaikan kepada DPRD Kabupaten Buton Utara melalui Badan Pembentukan Peraturan Daerah. Untuk selanjutnya kemudian akan diproses sesuai aturan yang berlaku di lingkup DPRD Kabupaten Buton Utara.

Berdasarkan hasil temuan dalam observasi lapangan terkait dengan persiapan pembentukan Perda sudah berjalan dengan efektif sekalipun partisipasi masyarakat secara langsung pada proses ini masih kurang optimal. Padahal pada tahapan ini, akan sangat ditentukan oleh masukan-masukan yang berasal dari masyarakat sebagai objek langsung setiap kebijakan yang dihasilkan oleh Pemerintah Daerah Kabupaten Buton Utara. Adanya partisipasi masyarakat dapat memberikan masukan sehubungan dengan persiapan pembentukan Perda yang akan lebih responsif terhadap persoalan masyarakat.

Sedangkan dalam observasi yang dilakukan terhadap sekretariat DPRD, mengenai proses pada tahap perumusan tugas Sekretariat DPRD hanya sebagai pendukung untuk menyediakan kelengkapan yang dibutuhkan oleh anggota DPRD, Komisi atau Badan dalam penyusunan Ranperda. Proses ini juga biasanya memanggil pihak dari LSM/OMS untuk memberikan masukan dan aspirasi 
terkait permasalahan yang akan dibahas dalam Ranperda.

\section{Tahap Pembahasan}

Sebagaimana proses pembentukan Perda, maka Rancangan Peraturan Daerah yang berasal dari DPRD atau Kepala Daerah dibahas oleh DPRD dan Kepala Daerah untuk mendapatkan persetujuan bersama. Dalam Peraturan DPRD Kabupaten Buton Utara disebutkan, Tahap ini sebagai tahap Pembicaraan Ranperda. Pada tahap pembicaraan dilakukan dalam dua tahap yakni Pembicaraan Tingkat I dan Pembicaraan Tingkat II.

Pada pembicaraan tingkat I, Ranperda baik yang menjadi usulan Kepala Daerah maupun DPRD disampaikan kepada Pimpinan DPRD, Komisi/ Gabungan Komisi dan Badan Pembentukan Perda dalam Rapat Paripurna DPRD. Hal-hal yang disampaikan dalam tahap pembicaraan tingkat I ini adalah penjelasana mengenai Ranperda yang diajukan oleh DPRD atau Kepala Daerah, kemudian dengar pendapat dari Komisi atau Kepala Daerah untuk selanjutnya dibawa pembahasan dalam Rapat Komisi/ Gabungan Komisi atau Panitia Khusus yang dibentuk bersama kepala daerah atau pejabat yang ditunjuk untuk itu.

Dari hasil observasi lapangan, pada tahap pembahasan Ranperda ini bisa menjalani proses yang panjang. Hal ini disebabkan oleh adanya tarik ulur kepentingan dan aspirasi. Disisi lain, menurut amatan peneliti proses ini juga menjadi sarana lobby politik tahap awal antara DPRD dan Kepala Daerah khususnya jika Ranperda yang dibahas berhubungan dengan pengesahan APBD.

Selain itu, sebagian Anggota DPRD hanya menyetujui satu atau dua PERDA dalam setahun walaupun merencanakan untuk membuat lebih banyak lagi. Anggaran daerah sering pula tertunda karena keterlambatan DPRD untuk menyetujuinya. Hal ini terjadi dikarenakan sistem partai yang terpusat membuat anggota DPRD menjadi lebih berpihak kepada partai sebagai sumber legitimasi daripada berpihak pada pemilih dan masyarakat.

\section{Tahap Penetapan}

Pembentukan

peraturan perundang-undangan pada dasarnya harus sesuai dengan beberapa aspek, antara lain aspek sosiologis, aspek filosofis dan aspek yuridis. Disamping itu, Perda disusun dengan tidak bertentangan dengan peraturan diatasnya. Untuk itu, sebelum penetapan Ranperda menjadi Perda, perlu diperhatikan dan dikomparasikan dengan peraturanperaturan diatasnya. 
Penetapan Ranperda menjadi Perda adalah tahapan selanjutnya setelah Pembahasan Ranperda dalam rapat paripurna bersama-sama Kepala Daerah atau Pejabat yang ditunjuk untuk itu. Pada proses ini, DPRD Kabupaten Buton utara akan menunjuk Komisi/ Gabungan Komisi atau Panitia Khusus, yang tugasnya untuk menyempurnakan redaksi dan muatan ranperda sebelum di tetapkan.

Sebagai sebuah proses politik yang tidak lepas dari berbagai kepentingan, pembentukan PERDA dalam artian sebagai produk legislasi DPRD, partisipasi masyarakat adalah keniscayaan. Disisi lain, dalam perumusannya mengesampingkan kepentingan publik serta "melenceng" dari arah pembangunan Hukum Nasional. Seperti yang tertuang dalam Undang-Undang Nomor 10 tahun 2004 tentang pembentukan Peraturan Perundang-Undangan disusun sebagai guideline bagi legislator daerah, dalam konteks proses dan substansi untuk memastikan bahwa produk hukum yang dihasilkan dapat selaras dengan tujuan pembangunan hukum di Indonesia.

Dalam proses observasi dan sejumlah wawancara penelitian yang telah dilakukan, memberikan penjelasan bahwa pada tahap ini Racangan PERDA bisa saja ditarik kembali untuk ditinjau kembali sebelum dibahas bersama-sama Kepala
Daerah. Hal ini disebabkan oleh beberapa alasan, misalnya saja Ranperda mendapat kritik dan penolakan dari kelompok masyarakat atau LSM terkait isi Ranperda. Penarikan Ranperda ini dilakukan oleh Pimpinan DPRD yang disertai oleh alasanalasan dilakukan hal itu. Menurut peneliti, pada tahap ini seringkali membuat Ranperda menjadi lamban untuk dijadikan sebagai PERDA dan diimplementasikan.

\section{Pengundangan dan \\ Penyebarluasan}

Peraturan Daerah yang telah ditetapkan oleh Kepala Daerah harus diundangkan dalam Lembaran Daerah agar memiliki kekuatan hukum dan mengikat masyarakat, yang pelaksanaannya dilakukan oleh Sekertariat Daerah. Dengan diundangkannya PERDA dalam lembaran resmi (Lembaran Daerah) maka setiap orang dianggap telah mengetahui. Dalam Peraturan DPRD Kabupaten Buton Utara No 1 Bulan November Tahun 2014 Pasal 121, menyatakan bahwa Rancangan Perda yang telah disetujui bersama oleh DPRD dan Bupati disampaikan oleh Pimpinan DPRD kepada Bupati untuk ditetapkan menjadi Peraturan Daerah.

Disisi lain, pada tahapan ini sebagai bagian dari legalisasi rancangan peraturan daerah menjadi PERDA. Tentunya dalam penetapannya telah dilakukan 
perampungan berbagai kelengkapan

PERDA misalnya saja naskah akademik sebelum hasil pembahasan Ranperda diajukan kepada Bupati selaku Kepala Daerah untuk disahkan dalam Lembaran Daerah.

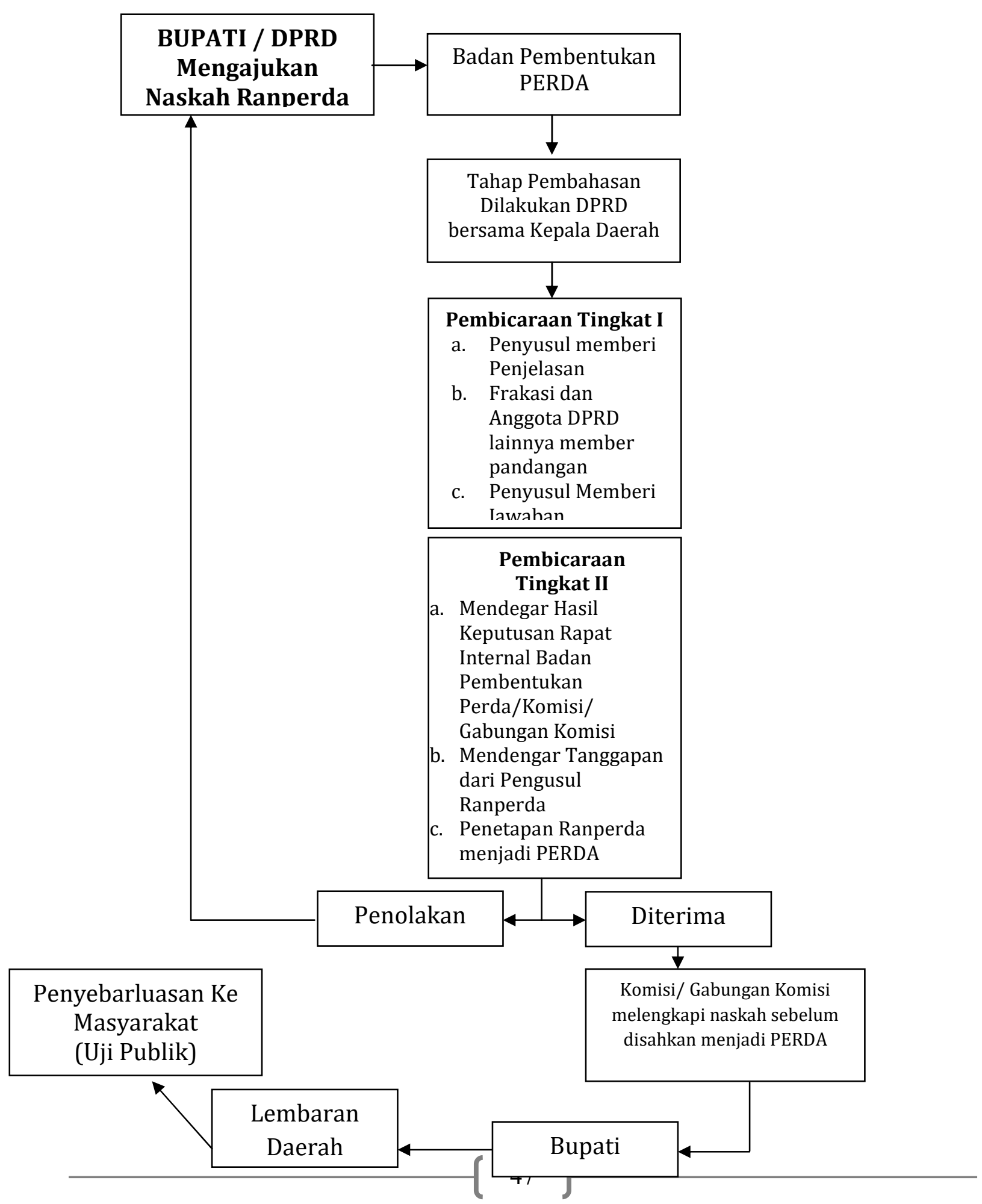




\section{Gambar 1 \\ Hasil Penelitian Tentang Alur Pembuatan PERDA}

(Sumber : Diolah dari Perda No 7 Tahun 2015 dan Peraturan

DPRD No 1 Bulan November Tahun 2015)

\section{b. Pembahasan}

Dalam observasi yang dilakukan terkait kinerja DPRD pada proses pembuatan PERDA dinilai belum maksimal, dimana menurut data yang dihimpun oleh penulis pada periode tahun 2014 sampai akhir tahun 2015 sedikitnya terdapat 35 PERDA yang dihasilkan DPRD Buton Utara bersama Kepala Daerah. Namun dari jumlah itu, hanya terdapat 3 PERDA yang merupakan inisiatif dari DPRD Kabupaten Buton Utara. Hal ini memberi gambaran bahwa inisiatif dalam proses legislasi di Kabupaten Buton Utara utamanya dalam inisiatif pembentukan PERDA hanya didominasi oleh Kepala Daerah.

Menurut amatan penulis, kinerja ini tentu berkorelasi dengan capaian yang dapat diberikan oleh DPRD Buton Utara dalam menjalankan salah satu tugasnya yakni legislasi. Tentunya dengan adanya produk hukum daerah atau peraturan daerah yang dihasilkan menjadi catatan bahwa kinerja yang ditunjukkan oleh DPRD Buton Utara berjalan sebagaimana mestinya. Dalam beberapa kesempatan memang dalam proses legislasi membutuhkan dinamika dan perdebatan yang cukup alot, seperti misalnya mengenai pembahasan Ranperda pemindahan Ibukota Buton Utara dari Ereke ke Buranga yang hingga saat ini belum bisa diselesaikan atau menemukan titik temu penyelesaian, bahkan disebutkan bahwa DPRD dan Bupati Buton Utara melanggar Peraturan Menteri Dalam Negeri tentang penetapan ibukota Buton Utara dan amanat Pemekaran Buton Utara

(http://www.rakyatsultra.com/butur/p olemik-dprd-dan-pemkab-tentangpemindahan-ibukota-butur/ diakses, 20/10/2015). 
Data Penetapan PERDA periode

tahun 2014 sampai Akhir tahun 2015

dapat dilihat pada Tabel 1.

Tabel 1.

Daftar PERDA Kabupaten Buton Utara 2014-2017

\begin{tabular}{|c|c|c|}
\hline NO & NAMA PERDA & INISIATIF \\
\hline 1. & Bangunan Gedung & Pemerintah Daerah \\
\hline 2. & $\begin{array}{l}\text { Rencana Pembangunan Jangka Panjang Daerah } \\
\text { (RPJPD) KabupatenButon Utara Tahun 2010- } \\
2025\end{array}$ & Pemerintah Daerah \\
\hline 3. & Pajak Penerangan Jalan & Pemerintah Daerah \\
\hline 4. & Pajak Reklame & Pemerintah Daerah \\
\hline 5. & $\begin{array}{l}\text { Pajak Pengambilan dan Pengolahan Bahan } \\
\text { Galian Mineral Bukan Logam dan Batuan }\end{array}$ & Pemerintah Daerah \\
\hline 6. & Retribusi Izin Mendirikan Bangunan & Pemerintah Daerah \\
\hline 7. & Retribusi Pelayanan Pasar & Pemerintah Daerah \\
\hline 8. & Retribusi Izin Usaha Perikanan & Pemerintah Daerah \\
\hline 9. & Retribusi Izin Penjualan Minuman Beralkohol & Pemerintah Daerah \\
\hline 10. & Retribusi Pelayanan Kesehatan & Pemerintah Daerah \\
\hline 11. & $\begin{array}{l}\text { Pembentukan Organisasi dan Tata Kerja } \\
\text { Kantor Pengelolah Hutan Lindung }\end{array}$ & Pemerintah Daerah \\
\hline 12. & $\begin{array}{l}\text { Perlindungan dan Pengelolaan Lingkungan } \\
\text { Hidup }\end{array}$ & Pemerintah Daerah \\
\hline 13. & $\begin{array}{l}\text { Perubahan Atas Peraturan Daerah Kabupaten } \\
\text { Buton Utara Nomor } 4 \text { Tahun } 2011 \text { Tentang } \\
\text { Penetapan Hari Ulang Tahun Kabupaten Buton } \\
\text { Utara }\end{array}$ & Pemerintah Daerah \\
\hline 14. & Pemerintah Desa dan Badan Permusyawaratan & DPRD \\
\hline
\end{tabular}




\begin{tabular}{|c|c|c|}
\hline & Desa & \\
\hline 15. & Penyelenggaraan Pelayanan Publik & DPRD \\
\hline 16. & Pedoman Teknis Peraturan Di Desa & DPRD \\
\hline 17. & $\begin{array}{l}\text { Tata Cara Pembentukan Produk Hukum } \\
\text { Daerah }\end{array}$ & Pemerintah Daerah \\
\hline 18. & Penyelenggaraan Bantuan Hukum & Pemerintah Daerah \\
\hline 19. & Penyelenggaraan Penanggulangan Bencana & Pemerintah Daerah \\
\hline 20. & Sistem Penyusunan APBD & Pemerintah Daerah \\
\hline 21. & $\begin{array}{l}\text { Perubahan Atas Perda Nomor } 11 \text { Tahun } 2011 \\
\text { tentang Retribusi Pemakaian Kekayaan Daerah }\end{array}$ & Pemerintah Daerah \\
\hline 22. & RetribusiTempat Rekreasi dan Olahraga & Pemerintah Daerah \\
\hline 23. & $\begin{array}{l}\text { Organisasidan Tata Kerja Badan Penanaman } \\
\text { Modal dan Pelayanan Perizinan Terpadu Satu } \\
\text { Pintu }\end{array}$ & Pemerintah Daerah \\
\hline 24. & $\begin{array}{l}\text { Perubahan Ketiga Atas Perda Nomor } 5 \text { tahun } \\
2008 \text { tentang Organisasidan Tata Kerja } \\
\text { Inspektorat, Bappeda dan Lembaga Teknis } \\
\text { Daerah Kabupaten Buton Utara }\end{array}$ & Pemerintah Daerah \\
\hline 25. & $\begin{array}{l}\text { Tuntutan Perbendaharaan dan Tuntutan Ganti } \\
\text { Rugi Keuangan dan Barang Milik Daerah } \\
\text { Kabupaten Buton Utara }\end{array}$ & Pemerintah Daerah \\
\hline
\end{tabular}

(Sumber: Sekretariat DPRD Buton Utara, 2017)

Nampaknya, produk hukum daerah Kabupaten Buton Utara dalam hal ini adalah PERDA, dalam penyusunannya lebih banyak didominasi oleh inisiatif Pemerintah Daerah. Kondisi ini tentu mengindikasikan bahwa, kinerja bidang legislasi dari DPRD Kabupaten Buton utara kurang produktif. Dalam observasi yang dilakukan oleh peneliti selama melakukan penelitian, berbagai sebab oleh karena dari seluruh PERDA tahun 2014-2015 yang dibahas oleh DPRD hanya berkaitan dengan urusan-urusan strategis pihak eksekutif daerah. Fungsi Kontrol terhadap kondisi masyarakat, menurut peneliti masih lemah misalnya saja terhadap para petani yang tidak mendapatkan bantuan dan seringkali tidak tepat sasaran jika ada bantuan. Tentu hal ini berimplikasi langsung dengan sejumlah indikasi yang turut 
mempengaruhi pelaksanaan fungsi legislasi DPRD Kabupaten Buton Utara.

Mengenai persoalan seperti diatas akan dapat mempengaruhi kinerja yang ditunjukkan oleh DPRD, khususnya dalam bidang legislasi. Dalam beberapa informasi mengenai permasalahan di wilayah Kabupaten Buton Utara, peran yang ditunjukkan oleh DPRD belum begitu optimal. Sebut saja misalnya dalam mengenai pemindahan Ibu Kota Kabupaten Buton Utara dari Ereke ke Buranga, juga beberapa masalah kemasyarakatan misalnya kekeringan air bersih oleh warga (http:// kendaripos.co.id /wargabutur-resah-kekeringan-air/diakses, 20/10/2015)

Untuk itu penting kiranya, memetakan beberapa faktor yang mempengaruhi peran DPRD khususnya dalam bidang legislasi di daerah. Hal ini sebagai bagian dari temuan penelitian, dan akan membantu dalam memahami fokus permasalahan dalam penelitian ini.

Disisi lain, secara yuridis memang dicantumkan dalam Perda No 7 Tahun 2015 bahwa partisipasi dapat dilakukan melalui; (a) Rapat Dengar Pendapat Umum; (b) Kunjungan Kerja; (c) Sosialisasi; (d) Seminar/Lokakarya; dan atau (e) Diskusi. Namun dalam perjalananya, dalam menyampaikan aspirasi masyarakat belum tahu kemana harus menyampaikan beberapa keluhannya. Dalam beberapa kesempatan misalnya demonstrasi oleh mahasiswa dan kelompok masyarakat, barangkali belum mewakili segenap aspirasi masyarakat secara umum. Karenanya, menurut amatan penulis dalam hal sarana aspirasi masyarakat belum optimal dalam artian belum ada sarana yang disediakan seperti misalnya kotak saran, rumah aspirasi atau media sarana lainnya.

\section{Kesimpulan}

Dari rangkaian pembahasan dalam penelitian ini, maka peneliti menyimpulkan bahwa pelaksanaan Fungsi Legislasi dalam Pembentukan PERDA oleh DPRD Kabupaten Buton Utara berjalan dengan baik sebagaimana mestinya, seperti yang di amanatkan Undang-Undang 23 Tahun 2014 Tentang Pemerintahan Daerah dan tercantum dalam PERDA Kabupaten Buton Utara Nomor 7 Tahun 2015 tentang Pembentukan Produk Hukum Daerah. Pembentukan PERDA ditingkat DPRD yakni melalui beberapa tahapan yakni Perencanaan, Penyusunan, Pembahasan yang didalamnya dilakukan Pembicaraan tingkat I dan II, Penetapan dan Pengundangan dalam Lembaran 
Daerah. Sekalipun demikian, dalam perjalanannya pembahasan PERDA lebih banyak adalah berasal dari inisiatif Pemerintah Daerah. Sedangkan, FaktorFaktor yang memengaruhi proses pelaksanaan fungsi legislasi DPRD Kabupaten Buton Utara diantaranya adalah Dinamika Politik, Kapabilitas Anggota, dan Ruang Aspirasi Masyarakat.

\section{Daftar Pustaka}

\section{Buku}

Bagir Manan, 2004. Teori dan Politik Konstitusi, Cetakan Kedua, Yogyakarta: FH UII Press

Budiarjo, Miriam, 2004. Dasar-Dasar Ilmu Politik, Edisi Revisi, Yogyakarta: Salemba.

Huda, Ni'matul, 2009. Hukum Pemerintahan Daerah, Bandung: Nusa Media

Haris, Syamsuddin. 2005, Desentralisasi dan Otonomi Daerah, Jakarta: LIPI Press

Josef, R. Kaho, 2005. Prospek Otonomi Daerah Di Negara Republik Indonesia, Jakarta: PT Rajagrafindo Persada

Karim, Hasmidha.,Rauf, Syukri.,Fitri, Fransisca, 2009. Laporan Penelitian Kondisi Organisasi Masyarakat Sipil (OMS) Kabupaten Buton Utara, Jakarta: Yappika.

Miles, Matthew B. Dan A. Michael Huberman, 2009., Analisis Data Kualitatif: Buku Sumber Tentang Metode-Metode Baru, Jakarta: Universitas Indonesia (UI-Press).
Syaukani HR, Afan Gaffar dan M, Ryass Rasyud, 2002. Otonomi Daerah Dalam Negara Kesatuan, Yogyakarta: Pustaka Pelajar Kerjasama dengan PUSKAP.

Soehartono. Wirawan, 2008. Metode Penelitian Sosial: Suatu Teknik Penelitian Bidang Kesejahteraan Sosial dan Ilmu Sosial Lainnya, Bandung: Rosda Karya

Slamet, Y. 2006. Metode Penelitian Sosial, Surakarta: Sebelas Maret University Press.

\section{Peraturan Undangan \\ Perundang-}

Undang-Undang Nomor 12 Tahun 2011 Tentang Pembentukan Peraturan Perundang-Undangan dan Prosedur Penyusunan Produk Hukum Daerah

Undang-Undang Nomor 23 Tahun 2014 Tentang Pemerintah Daerah

Undang-Undang Nomor 14 Tahun 2007 Tentang Pembentukan Kabupaten Buton Utara Provinsi Sulawesi Tenggara

Peraturan Dewan Perwakilan Rakyat Daerah Kabupaten Buton Utara Nomor 1 Bulan November Tahun 2015 tentang Tata Tertib Dewan Perwakilan Rakyat Daerah Kabupaten Buton Utara.

Peraturan Daerah Kabupaten Buton Utara Nomor 7 Tahun 2015 Tentang Tata Cara Pembentukan Produk Hukum Daerah

\section{Internet}

WWW.

Kabupatenbutur.go.ig/

Profil/diakses, 20/10/2015)

http://www.butonpos.com/suarabutur/pemkab-sosialisasikanperda-pemdes-dan-bpd/ diakses, 20/10/2015)

http://hariansultra.com/dprd-butonutara-godok-empat-raperdadesa/diakses, 20/10/2015) 
http://www.butonpos.com/suara-

butur/pemkab-sosialisasikan-

perda-pemdes-dan-bpd/ diakses, 20/10/2015)

https://m3sultra.wordpress.com/2010/

11/30/pemkab-butur-

rampungkan-perda-rtrw/

diakses, 20/10/2015)

http:// kendaripos.co.id /warga-buturresah-kekeringan-air/diakses, 20/10/2015) 